\title{
Food-scientific Investigations on So-called Crystalline Taro Occurring in the Child-corm of an Early-maturing Colocasia antiquorum Named cv. Ishikawa-wase
}

\author{
Ikuzo URITANT ${ }^{*}$ and Wakako TAKEUCHI ${ }^{*}$ \\ *Faculty of Home Economics, Nagoya Women's University, \\ 3-40, Shioji-cho, Mizuho-ku, Nagoya, Aichi 467
}

\begin{abstract}
So-called crystalline taro (Suisho-imo in Japanese) occurs often in the child-corm of an early-maturing Colocasia antiquorum named cv. Ishikawa-wase. The corm looks semitransparent at the lower part close to the binding site with the parent-corm when cut longitudinally into halves. The tissue cells of the lower part (showing semi-transparency) were proven to be alive by causing plasmolysis in a hypertonic solution. Observations under microscope and naked-eye after staining with iodine-iodide solution indicated that starch grains were not contained in the cells. According to the quantitative analyses, starch was present in very smaller amounts, and water in larger amounts in the lower part than in the upper part (not showing semi-transparency). The hardness of the corm was investigated after steaming, and the lower part was much softer than the upper part. This accorded with the absence of starch grains in the lower part. Thus, crystalline taro proved to be inferior to healthy taro from the viewpoint of nutrition and palatability. The method of discriminating crystalline taro from healthy taro without tissue destruction was devised by utilizing the difference in specific gravity between the lower and upper parts based on the absence or presence of starch grains. When the corms of crystalline taro were immersed in water, they assumed the perpendicular posture, taking the lower part upwards, but those of healthy taro assumed the horizontal posture in water. The observations on taro during growing at the fields and after harvest indicated that when the leaves and stems were unsatisfactorily grown, crystalline taro often occurred.
\end{abstract}

The authors were informed by a technical expert at a vegetable and fruit market in Nagoya that when taro corms of Colocasia antiquorum $\mathrm{cv}$, Ishikawa-wase arrive at the market, deteriorated taro corms called crystalline taro (Suisho-imo in Japanese) were sometimes mixed with the healthy corms. As explained by him, crystalline taro was seen in the child-corm of this cultivar, an earlymaturing cultivar, and looked semi-transparent at the lower part close to the binding site with the parent-corm when cut longitudinally into halves. Thus, we investigated on some subjects of crystalline taro such as the mechanism on showing semi-transparency, the condition of the cells in the semi-transparent part, the food quality after steaming, and a method of discriminating crystalline taro from health taro without tissue destruction. Further, we saw the taro fields where crystalline taro of ten occurred. This paper deals with the results of the above investigations on crytalline taro in special relation to food quality.

Independently of our works, T. ONo and $\mathrm{H}$. TAKEDA ${ }^{12)}$ performd the similar works, specially on the mechanism of the ocurrence of crystalline taro with reference to artificial injury, using some kinds of cultivars.

\section{Materials and Methods}

\section{Materials}

Batches of child-corms of Colocasia antiquorum Schott var. esculenta Engl. cv. Ishikawawase were provided by Nagoya Seika Co., the 
Nagoya Central Wholesale Market, Nagoya. The corms used were among those sent to the market from various growing areas in Japan, for the period from April, 1987 to June, 1988. Sometimes, the child corms of cv. Dotare and cv. Eguimo were also used. Taro corms named Gabi, an ordinary cultivar in the Philippines, belonging to late-maturing cultivars of C. esculenta, were also tested in the University of the Philippines at Los Banos in October, 1987. Unless otherwise stated, the corms of cv. Ishikawa-wase were used for the experiments. The chemicals used here were in reagent grade.

Separation of crystalline taro from healthy taro

The child-corms were cut into halves longitudinally. Then, the corms half cut were divided into two groups, crystalline taro and healthy taro, by watching the cut-surfaces. In the case of crystalline taro, semi-transparency was seen in the lower part, but not in the upper part. The lower and upper parts of both groups were subjected to some observations and analyses.

\section{Microscopic observations}

The tissue slices in the thickness of $0.1 \mathrm{~mm}$ or less were prepared by a razor blade, and observed under microscope with $40 \times 40$ magnifications. Iodine and iodide $\left(\mathrm{I}_{2}-\mathrm{KI}\right)$ solution in $0.1 \mathrm{~N}$ concentration was used for starch staining, and $0.8 \mathrm{M}$ sucrose solution with 1 $\mathrm{ppm}$ neutral red for plasmolysis ${ }^{3}$. $\mathrm{I}_{2}-\mathrm{KI}$ solution was also used to investigate the distribution pattern of starch in the tissue by naked eye (Photo 1).

Analyses of water and starch in the tissue

Water content was analyzed folowing the conventional method of heating at $105^{\circ} \mathrm{C}$. Amounts of starch were calculated based on the data of total reducing sugar (hydrolyzed by perchloric acid) assayed by phenol-sulfuric acid method $^{4)}$.

Hardness and mouth feel of the tissue after steaming

The corms cut into halves were divided into two groups, crystalline taro and healthy taro. They were steamed for 15 to $20 \mathrm{~min}$, and cooled at room temperature for 15 to $20 \mathrm{~min}$. Then, the hardness at the lower and upper parts of the 5 corms half-cut of each group was measured by a fruit hardness meter (universal type, Kiya Seisakusho Co., Tokyo). Usually, the hardness at each part of the corms was measured on two different sites, and indicated by the range between the lowest and highest values of the 10 measurements. Softening texture was also evaluated by mouth as mouth feel.

Discrimination of crystalline taro from healthy taro without tissue destruction

As will be shown in Results and Discussion, the lower part of crystalline taro does not contain starch grains. Hence, the specific gravity at the lower part must be smaller than at the upper part. When crystalline taro will be immersed in water, it will assume a perpendicular posture, taking the lower part upwards. On the other hand, healthy taro must have an equal value of specific gravity at any part. Thus, the taro will assume a horizontal posture, when immersed in water. Taking account of the above asumption, the posture of the corms when immersed in water was investigated. Thereafter, the occurrence of semi-transparency at the lower part was pursued.

Investigation on the occurrence of crystalline taro in some taro fields

In September, 1987, we visited Hineno Agricultural Cooperation Association, Izumi-sano City, Osaka Prefecture, and invesigated some taro fields near the Association, where taro corms were going to be harvested. Batches of the corms were taken from two different fields ; the one where the leaves and stems had been grown satisfactorily, and the other unsatisfactorily. Then, the semi-transparency and $\mathrm{I}_{2}-\mathrm{KI}$ stained starch distribution were investigated on the child- and grandchildcorms after half-cutting, at the Laboratory of the Association.

\section{Results and Discussion}

\section{Microscopic observations}

Microscopic observations indicated that starch grains were not present in any cell of 
Table 1 Observations on crystalline-taro cells under microscope

\begin{tabular}{lccll}
\hline \hline Parts & Semi-transparency & $\begin{array}{c}\text { Starch grains } \\
\text { per cell }\end{array}$ & $\begin{array}{l}\text { Starch stained } \\
\text { by } \mathrm{I}_{2}-\mathrm{KI} \text { soln. }\end{array}$ & Plasmolysis* \\
\hline Lower & Yes & None & $\begin{array}{l}\text { Positive as } \\
\text { fine fragments }\end{array}$ & Positive \\
Upper & No & Many & $\begin{array}{l}\text { Positive as } \\
\text { grains }\end{array}$ & Positive \\
\hline
\end{tabular}

* Plasmolysis was odserved in $0.8 \mathrm{M}$ sucrose solution with $1 \mathrm{ppm}$ neutral red.

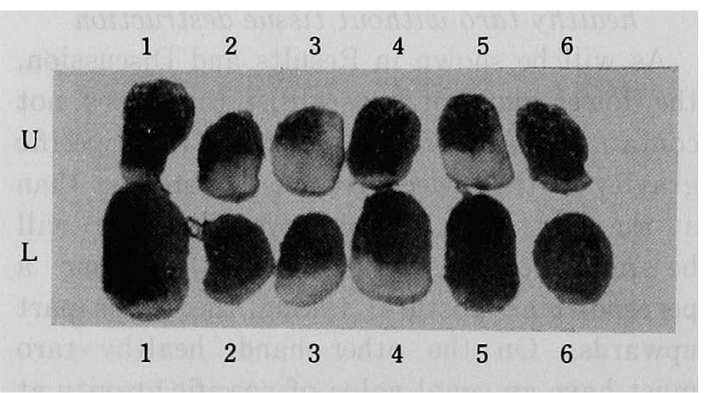

Photo 1 Corms of crystalline taro and healthy taro stained by $\mathrm{I}_{2}-\mathrm{KI}$ solution

Numbering of the corms : Upper side (U), from left to right: U 1, U 2, U 3, U 4, U 5 and $U 6$; Lower side (L), from left to right: L 1, L 2, L 3, L 4, L 5 and L 6. The corms numbered U 2, U 3, U 5, L 3 and L 4 were not stained at the lower parts, and are regarded as crystalline taro. The other corms (U 1, U 4, U 6, L 1, L 2, L 5 and L 6) not stained only at limited areas of the lower parts belong rather to healthy taro.

the lower part (showing semi-transparency) of crystalline taro, except for few fine starchfragments in a cell, which were positive to $\mathrm{I}_{2}-$ KI solution (Table 1 ). On the other hand, the tissue cells of the upper part (not showing semi-transparency) were filled by typical starch grains, positive to $\mathrm{I}_{2}-\mathrm{KI}$ solution. The fullness of starch grains in the cells was also observed in both sides of fresh taro. Further, nakedeye observations of crystalline taro after the application of $\mathrm{I}_{2}-\mathrm{KI}$ solution proved that starch was distributed at the upper part, but not at the lower part, in accordance with
Tadle 2 Amounts of water and starch in crystalline taro

\begin{tabular}{llcc}
\hline \hline Materials & Parts & $\begin{array}{c}\text { Water } \\
(\%)\end{array}$ & $\begin{array}{c}\text { Starch } \\
(\%)\end{array}$ \\
\hline Crystallie & Lower & 95.26 & 0.99 \\
& Upper & 76.45 & 10.43 \\
Healthy & Lower & 80.82 & 7.54 \\
& Upper & 79.63 & 8.24 \\
\hline
\end{tabular}

microscopic observations (Photo 1 ).

Plasmolysis was caused by sucrose hypertonic solution in the tissue cells of both lower and upper parts of crystalline taro. This demonstrated that tissue cells of the lower part lived, as those of the upper part did (Table 1). According to the experience of technical experts at some markets, when the lower part of crystalline taro is pushed by fingers, cellular sap is easily permeated from the tissue. Hence, they assumed that the lower part showing semi-transparency might be dead. However, this assumption was not correct, basd on the above observation. Further, it is concluded that crystalline taro is a kind of physiologically-deteriorated taro, but not microbiallydeteriorated taro, since the tissue of crystalilne taro was alive and indicated no infectious symptoms.

Amounts of water and starch in the tissue

In crystalline taro, water content was larger, but starch content extremely smaller in the lower part than in the upper part (Table 2). On the contrary, in healthy taro, there was almost no difference in contents of water and starch between the lower and upper parts (Table 2). Thus, the quantitative results ac- 
Table 3 Hardness of crystalline taro after steaming

\begin{tabular}{lllcc}
\hline \hline \multirow{2}{*}{ Dates measured } & Areas harvested & \multirow{2}{*}{$\begin{array}{l}\text { Crystalline or } \\
\text { Healthy }\end{array}$} & \multicolumn{2}{c}{ Hardness } \\
\cline { 5 - 5 } & & at lower part & at upper part \\
\hline May 21, 1987 & Okinoerabu & Crystalline & 0 & $0<$ \\
Oct. 26, 1987 & Shizuoka & Crystalline & $0.07 \sim 0.24$ & $0.34 \sim 0.64$ \\
" & " & Healthy & $0.28 \sim 0.47$ & $0.24 \sim 0.62$ \\
Oct. 29, 1987 & Kagoshima & Crystalline & $0.05 \sim 0.20$ & $0.38 \sim 0.57$ \\
Oct. 29, 1987 & Tottori & Crystalline & $0.14 \sim 0.23$ & $0.35 \sim 0.37$ \\
June 30, 1988 & Okinoerabu & Crystalline & $0.00 \sim 0.01$ & $0.04 \sim 0.09$ \\
" & " & Healthy & $0.09 \sim 0.19$ & $0.07 \sim 0.15$ \\
\hline
\end{tabular}

corded with the qualitative observations on $\mathrm{I}_{2}-\mathrm{KI}$ starch staining under microscope (Table 1) and naked eye (Photo 1). Those data indicated that semi-transparency in the lower part of crystalline taro was due to the absence of starch grains and fullness of water in the cells.

The child-corms of other cultivars including cv. Dotare, cv. Eguimo and Gabi in the Philippines were investigated on the distribution of starch by applying $\mathrm{I}_{2}-\mathrm{KI}$ solution. Each of them showed positive reaction to the reagent at all parts except for a limited small area adjacent to the binding site with the parentcorm. The child-corms of those culuivars did not show semi-transparency at the lower part. ONO and TAKEDA ${ }^{1 / 2)}$ investigated the relationship between some of cultivars and appearance of crystalline taro.

Hardness and mouth feel of the tissue after steaming

As shown in Table 3, the hardness of crystalline taro after steaming was smaller in the lower part (showing semi-transparency) than in the upper part. Since the vascular bundles were located more in the lower part, it was necessary to measure the hardness at the parenchymatous tissue, carefully avoiding the vascular bundles. In steamed healthy taro, there was almost no difference in the hardness between the lower and upper parts. The appearance of the hardness in the tissue was suggested to be based on the resistance of gelatinized starch to the pushing pressure.

We tested also the mouth feel of steamed taro. We felt too soft in the lower part of crystalline taro, compared with the upper part and with both sides of healthy taro. In the case of crystalline taro, starch was hardly present at the lower part, in which anomalous softness was found after steaming, under hardness-meter and in mouth.

Discrimination of crystalline taro from healthy taro without tissue destruction

It is important for the technical experts and dealers at the markets to discriminate crystalline taro from healthy taro. They use sometimes the method of pushing the lower part of the child-corms, and judge that in case cellular sap is permeated, the corms may be crystalline taro. However, this may be not always accurate, and the corms must be damaged by such pushing. Some other method of indicating more accurate discrimination was expected to be devised. Hence, we investigated the relation of the posture of the corms in water with the presence of semi-transparency in the corms, as described in Materials and Methods. We found that healthy corms assumed the horizontal posture, but crystalline taro assumed perpendicular posture, taking the lower part upwards, except for rotten corms, appearing to show some irregular posture.

Investigation on the ocurrence of crystalline taro in some taro fields

The child- and grandchild-corms harvested from the fields where the growth of the leaves and stems had been satisfactory did not indicate semi-transparency, but child-corms from the fields where the growth had been poor 
showed semi-transparency at the lower part, proving the occurrence of crystalline taro. However, grandchild-corms did not show semitransparency at any part. The starch-staining reaction with $\mathrm{I}_{2}-\mathrm{KI}$ solution was only negative at the lower part of child-corm of crystalline taro. We assume that the activities of photosynthesis and sucrose translocation to underground organs are sufficient in healthy taro, but deficient in crystalline taro, in which semi-transparency is caused in the child-corms by the deficiency of sucrose translocation to the child-corms, and by continuation of sucrose translocation from them to the grandchildcorms. Detailed experiments by ONO and TAKADA ${ }^{1) 2)}$ indicated the positive relation of the injury of the leaves with the insufficient accumulation of starch and appearance of crystalline taro in the child-corms.

Acknowledgement : We are grateful to Misses Y.Unno, S. Sakakibara, K. Miyamoto and H. MoRIMOTo for their cooperation with us in relation to the dissertation study for their graduation in March, 1988. We express our sincere thanks to Dr. K. TomiYama, Former Professor, Nagoya University, and Mr. Y. Mushiga,Meito Seika Co., the Nagoya Central Wholesale Market, for instructing us in the plasmolysis experiment, and providing us with many batches of taro corms with useful information, respectively. The senior author is indebted to Dr. V.V. Garcia, Institute of Food Science and Technology, University of the Philippines at Los Banos, Philippines, and Mr. T. IEJI, Hineno Agricultural Cooperation Association, Izumi-sano City, Osaka Prefecture, for helping him do the experiment on Gabi at the Institute, and guiding him to some different taro fields in Hineno area, respectively.

\section{References}

1) Ono, T. and TAKeda, H. : Bull. Chiba-ken Agric. Expt. Sta., No. 29, 71 (1988).

2) Ono, T. and TAKeda, H.: Agric. Hortic., 63, 1339 (1988).

3) Nozue, M., Tomryama, K. and Doke, N.: Physiol. Plant Pathol., 10, 181 (1977).

4) Hodge, J.E. and Hofreiter, B.T. : Methods in Carbohydrate Chemistry Vol. 1, WhisTLER, R.L. and WOLFROM, M.L. eds. (Academic Press, New York), p. 388 (1962).

(Received Sep. 29, 1989)

\section{サトイモわせ品種，石川早生の子いもに生じる 水晶芼の食品科学的調查}

\section{瓜谷郁三・竹内若子}

名古屋女子大学家政学部

（テ467 愛知県名古屋市瑞穗区汐路町 3-40）

石川早生の子いもには時折いわゆる水晶芋が見いださ れ，親いもとの接触部位（下部）が半透明の状隹を示す. その部位の細胞は高張溶液下で原形質分離を㓐起し，上 部の細胞之同様に生きているが，デンプン粒を持たず， 反対に水分を多量に含み，そのため半透明に見えること を知った．蒸煮後には下部は上部にくらべ余りにも軟ら かくなり，水晶芋は栄養・食品上，品質が落ちることが わかった．水晶芋では，デンプン粒の有無から下部と上 部の比重差を生じ，水に浸漬すると下部を上にして垂直 の姿勢をとるが，健全芋は水中で水平の姿勢をとること を見いだし，これを基にして組織を破壊することなく水 晶芼之健全芋を識別する簡便法を提示した。サトイモ㚼 での生育状况とそこから収礶した子いるの観察から，地 上部の生育のわるい畑からの子いもに水晶芋が多く発生 することを知った。 